\title{
Metoda śledzenia procesu i mechanizmy przyczynowe w badaniu stosunków międzynarodowych
}

\begin{abstract}
Streszczenie: W artykule przedstawiono jakościową metodę śledzenia procesu (process tracing) i jej przykładowe wykorzystanie w badaniu stosunków międzynarodowych. Po pierwsze, dokonano ogólnej charakterystyki metody. Po drugie, przedstawiono debatę toczoną w naukach społecznych na temat rozumienia mechanizmów przyczynowych i przyczynowego wnioskowania oraz użyteczności metody śledzenia procesu do testowania hipotez. Po trzecie, omówiono różnego rodzaju dyrektywy kierujące postępowaniem badawczym w ramach metody śledzenia procesu. Po czwarte, w końcowej części artykułu zademonstrowano implementację metody w nauce o stosunkach międzynarodowych na przykładzie analizy zakończenia zimnej wojny. W końcu sformułowano pewne wątpliwości związane $\mathrm{z}$ metodą.

Celem artykułu jest wprowadzenie do polskiej nauki o stosunkach międzynarodowych jakościowej metody badawczej, która nie jest wykorzystywana przez polskich badaczy, chociaż większość z nich określa swoje stanowisko metodologiczne jako jakościowe. Autor w szczególności uzasadnia i ilustruje przekonanie, że metoda śledzenia procesu może stanowić mocną propozycję w rozwiązywaniu problemów związanych z rozpoznawaniem stosunków przyczynowych w nauce o stosunkach międzynarodowych.

Autor posługuje się w artykule metodą analizy treści. Metoda śledzenia procesu została przedstawiona w oparciu o analizę tekstów uznanych zwolenników metody w filozofii nauki i nauce o stosunkach międzynarodowych oraz prac poświęconych problemom stosunków międzynarodowych badanych przy zastosowaniu tej metody.

Wyniki przeprowadzonej analizy pozwalają na sformułowanie rekomendacji do stosowania metody do badania stosunków międzynarodowych. Autor przedstawia również słabe strony metody, których istnienia powinien być świadomy każdy z niej korzystający.
\end{abstract}

Słowa kluczowe: śledzenie procesu, mechanizmy przyczynowe, testowanie hipotez, dyrektywy, zakończenie zimnej wojny

\section{Wprowadzenie}

$\mathbf{N}$ iektórzy badacze stosunków międzynarodowych explicite, inni implicite, martwią się, że badanie przypadków (case study) lub metody jakościowe (qualitative methods) znajdują się niżej w hierarchii postulowanych sposobów prowadzenia badań, aniżeli metody statystyczne lub randomizowane eksperymenty. Tymczasem od wielu lat poparcie dla jakościowych analiz, zarówno w naukach przyrodniczych, jak i społecznych, rośnie. Liczni ekonomiści, socjolodzy, psycholodzy, politolodzy i międzynarodowcy uważają, że metoda śledzenia procesu (process tracing, dalej SP) jest wartościowym narzędziem przyczynowego wnioskowania i wyjaśniania. Badaczy tych łączy przekonanie o znaczeniu generatywnych przyczynowych procesów i mechanizmów w przyczynowym wnioskowaniu i wyjaśnianiu. Skutkiem tego przekonania jest rosnący scepty- 
cyzm wobec możliwości oferowanych przez nawet zaawansowane metody statystyczne w rozpoznawaniu procesów i mechanizmów ${ }^{1}$. Metoda SP jest zatem uważana za mocną propozycję $\mathrm{w}$ rozwiązywaniu problemów związanych $\mathrm{z}$ rozpoznawaniem stosunków przyczynowych. Badacze są zainteresowani tą metodą wskutek rozczarowania brakiem eksplanacyjnej adekwatności sądów, które wiążą fakty lub zmienne bez ustanawiania sekwencji wydarzeń lub procesu, w wyniku którego jeden fakt lub zmienna generują inne fakty lub zmienne (Waldner, 2012, s. 69).

W polskiej literaturze o stosunkach międzynarodowych, jak wynika z empirycznej analizy artykułów opublikowanych w siedmiu czołowych polskich czasopismach naukowych poświęconych stosunkom międzynarodowym i polityce w latach 2007-2012, większość badaczy określa swoje stanowisko metodologiczne jako jakościowe. Jednak żaden z nich nie posłużył się w swoich badaniach metodą SP (Czaputowicz, Wojciuk, 2014, s. 18). Jedynym tekstem omawiającym tę metodę w polskiej literaturze politologicznej jest rozdział autorstwa Kamila Ławniczaka w pracy zbiorowej poświęconej metodom jakościowym i ilościowym w badaniu Unii Europejskiej. Autor przekonuje w nim o użyteczności metody i przedstawia praktyczne rady dotyczące jej stosowania (Lawniczak, 2013, s. 69-84).

\section{Filozoficzne podstawy metody śledzenia procesu}

Uwzględniając rozwój nowych ilościowych technik wnioskowania oraz metod eksperymentalnych, entuzjazm dla metod jakościowych może wydawać się niezrozumiały czy kłopotliwy. Dlaczego relatywnie prosta metoda, jaką jest SP, zdobywa akceptację i uznanie (Waldner, 2012, s. 66)? Odpowiedzi na to pytanie dostarczają nie tylko metodologiczne kwalifikacje metody SP, ale przede wszystkim nowe propozycje filozofii nauki i ich recepcja w poszczególnych dyscyplinach nauk społecznych. Za najbardziej ogólną przyczynę zachodzącej zmiany można uznać krytykę dominującego w XX wieku dedukcyjno-nomologicznego modelu eksplanacji. Drugą ważną przyczyną jest rozwój nowych modeli wyjaśniania opartych o koncepcję mechanizmów przyczynowych. Prace, między innymi, Mario Bunge (2006, 2009, 2012), Jona Elstera $(1989,1998,2007)$, Daniela Little (1998, 2010), Roya Bhaskara (1978, 1979, 2011), Henry E. Brady'ego i Davida Colliera (2010), wprowadzały przedstawicieli nauk społecznych do koncepcji wyjaśniania poprzez mechanizmy przyczynowe oraz do literatury o filozofii naukowego realizmu i krytycznego realizmu, w których koncepcja ta znajduje swoje ontologiczne fundamenty.

Zwolennicy metody SP skorzystali z tego intelektualnego fermentu przekonując, że może ona stanowić rodzaj mostu między Humeowskim rozumieniem przyczynowości jako powiązania (regularnościowy determinizm) i przyczynowością rozumianą poprzez mechanizmy, jako rodzaj łańcucha łączącego hipotetyczną przyczynę i skutek

${ }^{1}$ I ten sceptycyzm może dziwić, ponieważ w ostatnich latach ilościowe techniki przyczynowego wnioskowania dalece wykroczyły poza zwykłe wieloczynnikowe analizy i poszukiwanie korelacji. Zwolennicy metod ilościowych budują przyczynowe wnioskowania, posługując się modelami kontrfaktualnymi, korzystają z przyczynowych modeli graficznych oraz udoskonalają metody statystyczne: instrumentalnych zmiennych, nieciąłej regresji, estymatorów różnicy. 
(Hedström, Swedberg, 1998; George, Bennett, 2005; Hedström, 2008; Beach, Pedersen, 2013; Bennett, Checkel, 2015).

\section{Metoda śledzenia procesu}

Określenie „metoda SP” stało się etykietką obejmującą rozmaite podejścia. Andrew Bennett i Jeffrey T. Checkel mówią nawet o problemie „modnego hasła” (2015, s. 2). Przeglądając literaturę przedmiotu obejmującą okres od 1985 do 2015 roku można przywołać około dwudziestu definicji SP (Trampusch, Palier, 2016, s. 4-5). Początkowo definiowano SP jako metodę analizy procesów podejmowania decyzji (George, McKeown, 1985, s. 25). Obecnie dominuje jej rozumienie jako metody, której celem jest identyfikowanie lub testowanie hipotez o mechanizmach przyczynowych w celu skompensowania słabości analiz poszukujących jedynie korelacji. Objaśniając metodę, Derek Beach i Rasmus B. Pedersen, wskazują na chęć wyjścia za jej pomocą poza identyfikowanie jedynie korelacji między niezależnymi zmiennymi i skutkami na rzecz badania mechanizmów przyczynowych. Według autorów jest to wręcz jedyna metoda, która takie postępowanie badawcze umożliwia (Beach, Rasmus, 2013, s. 1-2). Andrew Bennett i Colin Elman podkreślają, że śledząc proces badacz może posługiwać się zarówno indukcją, jak i dedukcją w badaniu wydarzeń i ich sekwencji w poszczególnych case studies. Postępowanie indukcyjne może odsłonić potencjalnie przyczynowy proces, którego badacz nie teoretyzował a priori. Postępowanie dedukcyjne, o ile badacz dysponuje teorią, może sugerować jakie wydarzenie powinno pojawić się w badanym przypadku, jeśli teoria dostarcza dobrego wyjaśnienia. W zależności od teorii można zakładać wręcz zajście określonych wydarzeń i traktować je jako warunki konieczne (Bennett, Elman, 2007, s. 183). Zwracając uwagę na ten sam problem inni dowodzą, że SP pomaga analizować dwa typy procesów: zrealizowane i antycypowane (Rohlfing, 2012, rozdz. 6). David Waldner wskazując na kluczowe elementy SP (procesy, mechanizmy, heterogeniczne dane) definiuje metodę jako sposób przyczynowego wnioskowania oparty o konkatenacje (wiązanie poprzedniego z następnym), a nie kowariancje. SP posługuje się podłużnymi badaniami (obserwacja tych samych rzeczy i zjawisk w dłuższym czasie), w których danymi są sekwencje wydarzeń (indywidualne i kolektywne akty lub zmiany stanu) uzyskiwane w wyniku niestandaryzowanych obserwacji pojedynczych jednostek analizy (case study). Opierając się na analizie case study SP uprzywilejowuje wewnętrzną prawomocność uzyskiwanych rezultatów badawczych nad zewnętrzną prawomocnością. SP można wykorzystać do formułowania przyczynowych wnioskowań w sytuacji, gdy nie dysponujemy danymi pozwalającymi na poszukiwanie korelacji (Waldner, 2012, s. 68-69). Zwolennicy metody podkreślają, że jest ona szczególnie wartościowa z punktu widzenia ustanawiania cech wydarzeń tworzących indywidualne sekwencje (trwanie, porządek i tempo), a także wiążących je mechanizmów przyczynowych. W istocie nie ma alternatywy dla SP w analizie wydarzeń tworzących sekwencje i procesy badane w komparatywno-historycznym postępowaniu (Falleti, Mahoney, 2015, s. 212).

W podręcznikowej charakterystyce metody SP, Jeffrey T. Checkel wskazuje na śledzenie mechanizmu(ów) przyczynowego, działającego w danej sytuacji oraz staranne mapowanie procesu i badanie zakresu, w jakim jest on zgodny z wcześniejszymi, wy- 
prowadzonymi z teorii przewidywaniami o działaniu tego mechanizmu. Dane jakimi posługujemy się w SP są, przede wszystkim, jakościowe i mogą obejmować wspomnienia historyczne, analizy eksperckie, wywiady, artykuły prasowe i dokumenty. Ostatecznie, metoda SP jest zgodna i komplementarna z szeregiem innych metod stosowanych w empiryczno-pozytywistycznej tradycji badawczej. Metoda SP jest jednak stosowana zarówno przez empirycznie zorientowanych zwolenników teorii racjonalnego wyboru, jak i konwencjonalnych konstruktywistów (Checkel, 2008, s. 116). W innym podręczniku poświęconym metodom badania stosunków międzynarodowych, Andrew Bennett charakteryzując metodę SP, podobnie, wskazuje na sprawdzanie przy jej pomocy czy występują zmienne interweniujące między zakładaną przyczyną i obserwowanym skutkiem, zgodnie z przewidywaniami teorii. Celem postępowania badawczego jest zatem ustalenie, które $\mathrm{z}$ wielu możliwych wyjaśnień jest zgodne z nieprzerwanym łańcuchem danych, rozpoczynając od zakładanej przyczyny do obserwowanego skutku. Siła metody leży w fakcie, że wymaga ona wskazania ciagłości i kompletności w wyjaśnianiu danego przypadku. Oczywiście, muszą istnieć granice w badaniu teoretycznie niekończącego się łańcucha „krok po kroku” w procesach historycznych (Bennett, 2004, s. 22-23).

Chronologiczny przegląd definicji metody pozwala dostrzec proces jej rozwoju polegający na przechodzeniu od analizy procesu podejmowania decyzji na poziomie indywidualnym i odsłanianiu jego behawioralnych podstaw do badania mechanizmów, które mogą działać na poziomie grup społecznych.

Metoda SP jest szczególnie przydatna, gdy badacz potrafi zbudować przyczynowy łańcuch poprzez zidentyfikowanie przyczynowych mechanizmów. Mechanizmy te thumaczą zmiany stanów (spraw, którym jako faktom brakuje intencjonalności i zdolności do działania) w rzeczy, które realizują się, ponieważ ich przyczyną są działania (zachowania) aktorów. Łańcuch wydarzeń bez wskazania przyczynowych mechanizmów jest narracyjną historią. Wskazywanie mechanizmów bez wydarzeń jest teoretycznym studium, w którym wydarzenia symbolizują formalne modele lub nieformalne, werbalne przedstawienia. SP splata czynniki, wydarzenia i mechanizmy (Waldner, 2012, s. 70).

Należy powiedzieć, że zwolennicy metody SP traktują pojęcie „proces” poważnie. Oznacza to, między innymi, przekonanie, że analiza procesu jest niemożliwa bez danych jakościowych. Stąd dyspozycja do posługiwania się pierwotnymi źródłami (na przykład, dokumentami, wywiadami), a także drugorzędną literaturą opisującą specyficzne rezultaty, także w formie danych ilościowych. Metaforycznie rzecz ujmując, badacz śledzący proces dąży do identyfikacji „trybów i kół” mechanizmów przyczynowych i otwarcia ukrywających je ,czarnych skrzynek”.

Analizując literaturę przedmiotu poświęconą metodzie SP łatwo zauważyć, że badacze posługujący się nią przesuwają się nieustannie po symbolicznej osi, na której jednym końcu znajduje się empiria, na drugim zaś teoria. W rezultacie prawie wszyscy podkreślają istnienie dialektycznego związku między indukcją i dedukcją charakteryzującego SP. Podejścia poszczególnych autorów różnią się w zależności od relatywnej wagi nadawanej indukcyjnemu i dedukcyjnemu rozumowaniu. Decyzje o przyznaniu mniejszej lub większej wagi jednemu z rozumowań zależą, przede wszystkim, od zajmowanych stanowisk ontologicznych i epistemologicznych oraz stanu rozwoju badań nad danym problemem (Trumpusch, Palier, 2016, s. 7). Z tego punktu widzenia można wyróżnić bardziej indukcyjne i bardziej dedukcyjne typy SP. 
Przykładami bardziej indukcyjnych typów SP są: procedura śledzenia procesu (podejście do przyczynowej interpretacji w analizie pojedynczych przypadków przyjmujące formę SP poprzez wskazywanie kolejnych kroków w wyniku których, na przykład, przekonania wpływają na zachowania); wyjaśnianie historyczne (jego celem jest zazwyczaj wyjaśnienie wystapienia specyficznych wydarzeń w ograniczonej liczbie przypadków, takich jak powstanie Solidarności w 1980 roku lub wybuch I wojny światowej w 1914 roku; wsteczne śledzenie procesu (badacz śledzi wstecznie proces przyczynowy, który doprowadził do określonego rezultatu, na każdym etapie wnioskując z kontekstu, co złożyło się na określoną przyczynę. Ten wsteczny proces zakończy się sukcesem, jeśli doprowadzi badacza do ,pierwszej przyczyny”. W indukcyjnym typie SP badacz rozpoczyna postępowanie od obserwacji lub historycznych danych. Następnie bada, czy dane pozwalają na identyfikację interweniujących zmiennych, mechanizmów przyczynowych lub łańcucha przyczynowego. Celem tego typu SP jest, przede wszystkim, dążenie do zbudowania teorii poprzez tworzenie hipotez i odsłanianie specyficznych lub nowych mechanizmów przyczynowych (Trampusch, Palier, 2016, s. 8).

Przykładami bardziej dedukcyjnych typów SP są: testowanie procesu przewidywania (badacz rekonstruuje łańcuch wydarzeń lub decyzji, poprzez który początkowe warunki analizowanego przypadku przekształcają się w jego rezultaty; związek przyczyna-skutek między niezależną zmienną i rezultatem jest rozpakowywany i dzielony na mniejsze kroki; następnie badacz poszukuje obserwowalnych danych dla każdego kroku; procesy przewidywania są często wyjątkowe, żadna inna teoria nie przewiduje tego samego wzorca wydarzeń, dlatego też SP oferuje często mocny test dla danej teorii); proces weryfikacji (testowanie czy obserwowany proces potwierdza przewidywania sformułowane wcześniej w oparciu o teorię); metoda kongruencji (badacz posługuje się teorią dedukcyjną lub empiryczną generalizacją w celu sformułowania przewidywania/ wyjaśnienia wyniku zmiennej zależnej; jeśli wynik jest zgodny z przewidywaniem istnieje możliwość związku przyczynowego; badacz rozpoczyna postępowanie od teorii i próbuje ocenić jej zdolność do wyjaśniania lub przewidywania wyniku w konkretnym przypadku). W dedukcyjnym typie SP badacz rozpoczyna badanie od teorii i ocenia prawomocność empirycznych przewidywań wyprowadzanych z teorii poprzez porównanie danych dotyczących badanego przypadku $\mathrm{z}$ przewidywaniami teorii $\mathrm{w}$ formie hipotez o mechanizmach przyczynowych.

Zamiast gromadzenia danych ilościowych badacz posługujący się metodą SP gromadzi obserwacje odnoszące się do poszczególnych kroków w łańcuchu przyczynowym prowadzącym od przyczyny do skutku. Zakres zgromadzonych tym sposobem „danych” jest funkcją długości łańcucha przyczynowego i pozyskanych obserwacji służących poparciu każdego kroku. Forma danych zależy od przyczynowej struktury teoretyzowanej w każdym badanym przypadku. Dane te nie poddają się ilościowej standaryzacji, ponieważ są w wysokim stopniu wrażliwe na szczególną naturę każdego procesu, który jest przedmiotem obserwacji. Badacze akceptują takie podejście do problemu danych, ponieważ są przekonani, że każdy badany przypadek jest wyjątkowy. W związku z tym, także poszukiwanie zewnętrznego kryterium pozwalającego rozstrzygać o prawomocności wiedzy jest uznawane za cel iluzoryczny. Liczni badacze kwestionują ,[...] założenie o przyczynowej homogeniczności, które mówi, że ceteris paribus, równe wartości niezależnej zmiennej wytwarzają równe wartości zależnej zmiennej” (Waldner, 2012, s. 71). 


\section{Mechanizmowe rozumienie przyczynowości}

Debata toczona w naukach społecznych, także przez politologów i badaczy stosunków międzynarodowych, o mechanizmach przyczynowych wzbudza od kilku lat rosnące zainteresowanie i dostarcza pozytywnych rezultatów. Najważniejszym jest wzrastająca świadomość różnicy między korelacją a przyczynowością. Niestety, istnieje także istotna niepewność jak należy rozumieć mechanizmy i mechanizmowe wyjaśnianie.

Wśród zwolenników mechanizmowego wyjaśniania występuje wiele różnic w definiowaniu mechanizmów przyczynowych. Kontekst tych różnic pomaga zrozumieć filozof nauki Wesley C. Salmon (1998, s. 70-72). W latach 70. XX wieku Salmon był przekonany, że przy pomocy statystycznych modeli naukowego wyjaśniania można wyrazić podstawowe przyczynowe pojęcia i model ten dostarczy tego, czego brakowało w podejściu przyczynowym. Jednak już w latach 80 . dominowało przekonanie, że jest to niemożliwe. W związku z tym uwagę skierowano ku próbom wyjaśnienia pewnych przyczynowych mechanizmów, w szczególności przyczynowych interakcji i przyczynowych procesów. Celem było odróżnienie procesów, które są przyczynowe od procesów, które takimi nie są (procesy przyczynowe versus pseudo-procesy), to znaczy rozróżnienie między krzyżującymi się procesami, które są realnie przyczynowymi interakcjami od tych, które takimi nie są. Podstawowa idea, która stała za potrzebą tego rozróżnienia głosiła, że dwa procesy są przyczynową interakcją jeśli oba zostaną zmodyfikowane w wyniku skrzyżowania się w sposób, który wykracza poza moment skrzyżowania, nawet w wyniku braku dalszych skrzyżowań. Na przykład, kiedy dwie bile bilardowe zderzą się, stan ruchu każdej z nich zostaje zmodyfikowany w sposób, który wykracza (trwa) poza punktem skrzyżowania się. Zatem, proces jest przyczynowy, jeśli jest zdolny przekazać cechę (znak), to znaczy, jeśli jest zdolny wejść w przyczynową interakcję. Na przykład, wiązka białego światła staje się i pozostaje czerwona, jeśli przechodzi przez czerwone szkło, zaś szkło absorbuje pewną ilość energii w wyniku tej samej interakcji. Tym niemniej, nie wszystkie krzyżujące się procesy przyczynowe są interakcjami przyczynowymi. Na przykład, dwie krzyżujące się wiązki białego światła nakładają się na siebie w punkcie skrzyżowania, ale po jego opuszczeniu kontynuują swój bieg, jak gdyby nic się nie stało. W efekcie, Salmon przyjmuje, że przyczynowymi są procesy, które są , [...] zdolne transmitować energię, informację i przyczynowy wpływ z jednej części czasoprzestrzeni do innej” (Salmon, 1998, s. 71). Zatem, procesy przyczynowe są tymi przyczynowymi powiązaniami, o których mówił D. Hume, ale których nie potrafił wskazać, zaś mechanizmy przyczynowe niekoniecznie muszą być deterministyczne. Ponadto przyczynowe mechanizmy interakcji są silnie lokalne, to znaczy nie ma w nich miejsca na to, co A. Einstein nazywał „upiornym działaniem na odległość” (chociaż kwantowa mechanika wydaje się podważać zasadę lokalnej przyczynowości). Salmon proponuje nazywać koncepcję wyjaśniania, która wyłania się z tych uwarunkowań jako przyczynowo-mechaniczną.

Oparte o koncepcję mechanizmu podejście do społecznej teorii ma dalej idące ambicje, aniżeli tylko deskrypcja wyjątkowej sekwencji wydarzeń prowadząca od jednej sytuacji do następnej. Wartość metody SP jest zatem związana, przede wszystkim, ze sposobem konceptualizacji mechanizmów przyczynowych. Czym są zatem mechanizmy przyczynowe i jak się je rozumie w naukach społecznych? Jeśli zrównamy mechani- 
zmy przyczynowe ze zmiennymi interweniującymi, to SP może ułatwić przyczynowe wnioskowanie, ale w minimalnym stopniu pomoże w przyczynowych wyjaśnieniach. Istotę wyjaśniania większość badaczy rozumie nadal jako ukazywanie tego co szczególne poprzez to co ogólne. Podejście to zakłada, że w świecie społecznym istnieją ogólne typy mechanizmów działające zgodnie z tymi samymi logicznymi zasadami (Hedström, Swedberg, 1998, s. 1). W tym ujęciu odsłanianie mechanizmu można rozumieć jako tworzenie usystematyzowanego zbioru twierdzeń, które dostarczają prawomocnego wyjaśnienia jak dwa byty są ze sobą powiązane. Taka koncepcja przyczynowego wyjaśniania różni się istotnie od klasycznego modelu dedukcyjno-nomologicznego proponowanego przez Carla Hempla (Hempel, 1942, s. 35-48). Według Hempla wyjaśniamy, dokonując subsumpcji wydarzenia (faktu obserwacyjnego), pod prawo ogólne. Satysfakcjonujące wyjaśnienie musi zawierać ogólne obejmujące prawo (general covering law) i określenie warunków, w których prawo to stosuje się do konkretnego przypadku (faktu obserwacyjnego). Według Hempla deterministyczne prawa są całkowicie nieprawdopodobne w życiu społecznym. Nauki społeczne mogą zatem starać się formułować „prawa” o charakterze probabilistycznym, to znaczy dowodzić, że określone wydarzenie nastapi z pewnym prawdopodobieństwem, jeśli spełnią się określone warunki. Jeśli ,probabilistyczne prawa" ukazują nam jedynie statystyczne korelacje (Humeowskie powiązania) między czynnikami, musimy uznać, że model Hempla w istocie nie pozwala na uzyskiwanie wyjaśnień, a jedynie na uzasadnianie przewidywań. W tym znaczeniu model Hempla jest przykładem postępowania badawczego zezwalającego na posługiwanie się w naukach społecznych wyjaśnieniami ze wspomnianą, ,czarną skrzynką”, ponieważ nie wymaga wskazania mechanizmu wiążącego explanans (to co wyjaśnia) i explanandum (tego co wyjaśniane). Na przykład, sąd, że spadający barometr jest przyczyną sztormu jest w pełni zgodny z modelem dedukcyjno-nomologicznym, ale przecież każdy wie, że barometry nie są przyczyną sztormu. Ten brak w szczególny sposób przyciąga uwagę badaczy do mechanizmowego wyjaśniania, które obiecuje skuteczną pomoc w odróżnieniu przyczynowości od statystycznej korelacji i zrozumienie dlaczego obserwujemy to, co obserwujemy. Można powiedzieć, że „ostateczne” wyjaśnienie to wyjaśnienie bez „czarnej skrzynki”. Dlatego, jeśli chcemy w wyniku SP uzyskiwać adekwatne wyjaśnienia przyczynowe, musimy odróżnić mechanizmy od zmiennych interweniujących. Mechanizmy wyjaśniają, ponieważ obejmują niezmienne przyczynowe własności (Waldner, 2012, s. 67). Idea, że wyjaśnienia w naukach społecznych powinny opierać się raczej na przyczynowych mechanizmach, aniżeli na modelu dedukcyjno-nomologicznym zyskiwała na popularności w ostatnich dwudziestu latach (Ylikoski, 2012, s. 21). Podobny „mechanizmowy zwrot” pojawił się także w filozofii biologii i psychologii. Warto zaznaczyć, że rozumienie mechanizmów przez biologów (na przykład, synteza protein) opierające się na wskazywaniu ciąłych przestrzenno-czasowych procesów lub zorganizowanych systemów wydaje się mało użyteczne dla zrozumienia społecznych mechanizmów, które wprawdzie operują pojęciem agentów, ale których działania nie tworzą ciagłego przestrzenno-czasowego procesu i nie pozwalają się w pełni opisać poprzez ich organizację.

Badacze poszukują odpowiedzi na pytania jak rzeczy działają, to znaczy jakie są ich mechanizmy. Nie dziwi zatem, że znakiem firmowym współczesnej nauki jest raczej poszukiwanie mechanizmów stojących za faktami, aniżeli gromadzenie danych o faktach 
i szukanie korelacji między nimi (Bunge, 2006, s. 119). Ilustracyjnego politologicznego przykładu mechanizmowego podejścia dostarcza S. Lipset definiując demokrację jako społeczny mechanizm służący rozwiązywaniu konfliktowych interesów grup społecznych przy minimalnym użyciu siły i maksymalnym konsensusie (Lipset, 1959, s. 92). Demokrację możemy zatem rozumieć jako mechanizm sprzyjający partycypacji; partycypacja jest mechanizmem wzmacniającym spójność społeczną, ta sprzyja utrzymywaniu społecznej stabilności, która wzmacnia demokrację. W tym objaśnieniu cztery mechanizmy są powiązane w samopodtrzymujący się łańcuch przyczynowy. Analiza mechanizmowego wyjaśniania, zarówno w naukach przyrodniczych, jak i społecznych wskazuje, że mechanizm jest rozumiany jako proces lub sekwencja stanów w określonym systemie. Przez system możemy rozumieć złożony obiekt, którego części lub komponenty są ze sobą w określony sposób powiązane. Powiązania te są logiczne w przypadku konceptualnego systemu, takiego jak teoria lub materialne w przypadku takich systemów jak atom, komórka, rodzina czy system międzynarodowy. Pozycje, jakie zajmują względem siebie elementy tworzące system, składają się na jego strukturę. Mario Bunge, filozoficzny realista, ontologię w której pojęcia systemu i mechanizmu zajmują centralne miejsce nazywa systemizmem, który stanowi alternatywę zarówno dla indywidualizmu, jak i holizmu (Bunge, 2006, s. 128).

Chociaż nie wszyscy tak postępują, warto odróżniać system od jego mechanizmu(ów). Często bowiem mechanizmowe wyjaśnianie zamyka się w ramach metodologicznego indywidualizmu. W tym przypadku badacze poszukujący mechanizmowych wyjaśnień przywołuja ,,przyczynowego agenta”. Według krytycznego realisty Roya Bhaskara, aby nauka była możliwa, świat musi składać się z trwałych i transfaktualnie aktywnych mechanizmów. Społeczeństwo zaś to zbiór sił, wprawdzie nieredukowalnych, ale obecnych jedynie $\mathrm{w}$ intencjonalnych działaniach ludzi. Ludzie muszą być przyczynowymi podmiotami sprawczymi (causal agents) zdolnymi samoświadomie oddziaływać na świat, chociaż robią to wyobrażając sobie także istnienie głębszych struktur, które w złożony sposób determinują wszystkie zjawiska świata, w którym żyjemy (Bhaskar, 2008 (1978), s. 9). Ta centralna zasada metodologicznego indywidualizmu jest nierozerwalnie związana z ideą mechanizmowego podejścia poprzez konieczność wskazania explicite w wyjaśnianiu podstawowych generatywnych mechanizmów wiążących jedno wydarzenie lub fakt z innymi oraz działań konstytuujących to powiązanie. Mechanizmy, aby mogły wyjaśniać powiązania powinny być rozumiane w kategoriach ich generatywnych zdolności. George i Bennett (2005, s. 137) definiują mechanizmy przyczynowe jako ostatecznie nieobserwowalne fizyczne, społeczne lub psychologiczne procesy poprzez które działają agenci dysponujący przyczynowymi możliwościami, ale jedynie w specyficznych kontekstach lub warunkach, dokonując transferu energii, informacji lub materii do innych podmiotów. Robiąc to przyczynowi agenci zmieniają cechy, możliwości lub skłonności tych podmiotów w sposób, który utrzymuje się do momentu, w którym działają na nie kolejne mechanizmy przyczynowe.

Mechanizmy są zatem procesami zachodzącymi w konkretnych (materialnych) systemach (fizycznych i społecznych). Przykładami mechanizmów są: podział pracy, głosowanie, wojskowe ekspedycje, elektryczne i chemiczne sygnały biegnące w neuronowych sieciach czy rywalizacja seksualna. Konceptualne i semiotyczne systemy, takie jak teorie lub języki, chociaż składają się z elementów i posiadają struktury, nie posiadają 
mechanizmów. Powodem tego jest fakt, że zmienność lub energia jest definiującą własnością materii, zarówno fizycznej, chemicznej, biologicznej, jak i społecznej. Ponieważ różne mechanizmy mogą działać równocześnie w tym samym systemie i inferować ze sobą, wygodne jest odróżnianie mechanizmów istotnych od nieistotnych. Z istotnym mechanizmem w systemie wiąże się jego szczególne funkcjonowanie lub aktywność; nieistotne mechanizmy mogą pojawiać się w systemach różnego typu.

Istnieje naturalna tendencja, aby myśleć o wszystkich procesach, a zatem także mechanizmach, jako przyczynowych (lub deterministycznych). I chociaż wiele procesów ma charakter losowy (chaotyczny), można je uważać za szczególne przypadki przyczynowości, w których rezultaty zależą krytycznie od warunków początkowych. Jon Elster wyraża ideę mechanizmu jako często występujące i łatwo rozpoznawalne przyczynowe wzorce, które uruchamiają się w ogólnie nieznanych warunkach lub z nieokreślonymi konsekwencjami (Elster, 1998, s. 45). Przy takim rozumieniu, mechanizmy pozwalają nam wyjaśniać, ale nie przewidywać. Na przykład, być może dla każdego dziecka, które staje się alkoholikiem ze względu na wychowanie w alkoholowym środowisku, inne dziecko unika alkoholu w odpowiedzi na to samo środowisko. Obie reakcje zawierają mechanizmy: postępowania na wzór rodziców i postępowania odmiennego. Nie możemy przewidzieć kim stanie się dziecko wychowane w alkoholowym środowisku, ale jeśli stanie się abstynentem lub alkoholikiem, możemy założyć, że wiemy dlaczego.

Elster uważa, że naukowe prawo jest antonimem mechanizmu. Prawo zakłada, że przy danych warunkach początkowych wydarzenie danego typu (przyczyna) zawsze doprowadzi do wydarzenia innego typu (skutek). Wbrew stanowisku Elstera można założyć jednak, iż fakt, że w pewnych przypadkach, w istocie w zdecydowanej ich większości, mechanizmowe prawa są nieznane, nie dowodzi, że one nie istnieją. W badaniach społecznych prawa i mechanizmy są konieczne, ale niewystarczające do wyjaśniania, ponieważ wszystko co społeczne jest raczej konstruowane niż odkrywane. Wyjaśnienia wybuchu wojen odwołują się do bardzo wielu różnych przyczyn. We wszystkich tego rodzaju przypadkach wyjaśnianie polega na wskazaniu lub założeniu istnienia mechanizmu. Do wybuchu wojny prowadzi proces, niezależnie czy jego charakter jest przyczynowy, losowy, czy mieszany, który powoduje, że system zachowuje się w określony sposób. Za M. Bunge zasadne jest, i tak tutaj postępuję, nazywać ten typ wyjaśniania mechanizmowym, ponieważ nie wszystkie mechanizmy są mechaniczne. Poszukiwanie mechanizmów oznacza, że celem badania nie jest jedynie znalezienie korelacji między zmiennymi lub wydarzeniami, ale zdolność do specyfikacji społecznych „zębatek i kół”, które doprowadziły do powstania tego stosunku (Elster, 1989, s. 3).

Widać brak konsensusu w kwestii rozumienia i definicji przyczynowego mechanizmu. Chociaż zwykle badacze uznają taki stan rzeczy za objaw niedojrzałości i powód frustracji, sądzę, że nie musi to stanowić istotnego problemu. Byty i procesy badane przez różne nauki są heterogeniczne i nie wydaje się możliwe uzgodnienie jednej definicji mechanizmu obejmującej wszystkie badane pola. Tym niemniej możliwa jest ogólna charakterystyka mechanizmów. Po pierwsze, mechanizm zawsze jest mechanizmem czegoś, i może być identyfikowany poprzez skutek lub zjawisko, które wytwarza. Po drugie, mechanizm jest nieredukowalnie pojęciem przyczynowym odnoszącym się do przyczynowych procesów wytwarzających skutek. Po trzecie, mechanizm posiada strukturę. Kiedy oparte o mechanizm wyjaśnienie otwiera „czarną skrzynkę” znajdującą się 
między przyczyną i skutkiem, pozwala „zobaczyć” jak tworzące go byty i ich własności, aktywności i stosunki wytwarzają skutek. Po czwarte, istnieje hierarchia mechanizmów. Jeśli mechanizm na jednym poziomie składa się z bytów o określonych właściwościach i aktywnościach można zakładać, że na niższym poziomie istnieją mechanizmy, które objaśniają ten wyższy poziom. Taki łańcuch wyjaśnień ma swój koniec, na przykład, w wyjaśnieniach opartych o fundamentalne procesy fizyczne (Ylikoski, 2012, s. 22-23).

W literaturze poświęconej SP łatwo zidentyfikować dwie ontologie mechanizmów przyczynowych. Jedna zakłada ich deterministyczny charakter: działanie określonego mechanizmu zawsze prowadzi do wytworzenia specyficznego dla niego rezultatu. Druga opowiada się za probabilistycznym rozumieniem przyczynowości, dowodząc, że mechanizmy wchodzą $\mathrm{w}$ interakcje $\mathrm{z}$ innymi mechanizmami albo, inaczej mówiąc, $\mathrm{z}$ kontekstem, w którym działają. Zatem, rezultaty procesu, w ramach którego operują nie mogą być zdeterminowane a priori przez rozpoznanie działającego mechanizmu. Rozumienie mechanizmu albo jako jednoznacznego związku między X i Y albo jako „generatywnego mechanizmu" znajduje swoje implikacje w postępowaniu SP.

\section{Testowanie hipotez}

Z definicji, hipotezy wykraczają poza dane, w oparciu o które są konstruowane. Dzieje się tak co najmniej przy wystąpieniu jednego z dwóch powodów. Hipotezy są pewnego rodzaju ,skokiem” od częściowych danych do wszystkich możliwych danych albo zawierają pojęcia (na przykład, suwerenność, system międzynarodowy), które nie mają charakteru empirycznego. Ponieważ dane nie wytwarzają hipotez, muszą one zostać wymyślone.

Niektóre nauki przyrodnicze (fizyka, chemia, biologia) w szerokim zakresie posługują się eksperymentem, w innych (paleontologia, geologia, astronomia) dominuje obserwacja. W nauce o stosunkach międzynarodowych (dalej NSM) eksperymenty są w zasadzie niewykonalne, za wyjątkiem, do pewnego stopnia, symulacji konfliktu. Dla badacza stosunków międzynarodowych obserwacja jest zatem podstawową metodą testowania hipotez. Analizy oparte na obserwacji można sprowadzić do dwóch typów: (1) analizy statystycznej (large-n), w której bada się dużą liczbę przypadków poszukując korelacji między zmiennymi, które wybiera się w oparciu o przewidywania teorii oraz (2) studium przypadku (case study lub small-n), w którym bada się szczegółowo co najmniej jeden przypadek, sprawdzając czy wydarzenia przebiegają w przewidywany sposób i czy podmioty sprawcze (jeśli przedmiotem badania jest ludzkie zachowanie) działają w sposób zakładany przez teorię. Na pytanie, która metoda (eksperyment, large- $n$, studium przypadku) jest najlepsza, Stephen Van Evera odpowiada, ta która pozwala na przeprowadzenie najmocniejszych testów. Lepiej przeprowadzić więcej testów niż mniej; mocniejsze testy są lepsze niż słabsze; wiele mocnych testów jest najlepszych, jeśli dysponujemy metodami umożliwiającymi ich przeprowadzenie. To struktura dostępnych danych decyduje o tym, która metoda jest mocniejsza dla testowania danej hipotezy (Van Evera, 1997, s. 29). Równocześnie, zarówno pewność, jak i unikalność testów są kwestią stopnia. Wraz ze wzrostem i spadkiem stopnia pewności i unikalności hipotezy, wzrasta i spada także siła testu. Van Evera proponuje cztery typy testów, róż- 
niące się kombinacją siły i słabości: testy obręczy (hoop tests), testy dymiącego pistoletu (smoking-gun tests), podwójnie decydujące testy (doubly-decisive tests) i testy piórka na wietrze (straw-in-the-wind tests). (1) Testy obręczy: hipotezy o wysokiej pewności i braku unikalności mogą zostać sfalsyfikowane. Oblanie testu „zabija” hipotezę (teorię, wyjaśnienie), ale jego przejście jej nie potwierdza. Na przykład, „czy oskarżony był w kraju w dzień popełnienia przestępstwa?" Jeśli nie, jest on niewinny, ale wykazanie, że był w mieście, w którym go dokonano, nie czyni go winnym. Aby pozostać wiarygodną hipoteza musi „przeskoczyć przez obręcz" jaką stanowi dla niej test, ale przejście tego testu jej nie uprawomocnia. (2) Testy dymiącego pistoletu: hipotezy o wysokiej unikalności i braku pewności jeśli przejdą test zostają silnie potwierdzone, zaś jeśli go nie przejdą wyjaśniają nam niewiele. Na przykład, dymiący pistolet widziany w ręce podejrzanego w chwile po oddaniu strzału wydaje się konkluzywnym dowodem winy, ale podejrzany niewidziany z dymiącym pistoletem nie oznacza niewinnego. (3) Podwójnie decydujące testy: hipotezy o wysokiej unikalności i wysokiej pewności jeśli przejdą test zostaną potwierdzone, jeśli nie - obalone. Na przykład, jeśli bankowa kamera zarejestrowała twarze złodziei, nagrany film jest decydujący na dwa sposoby: czyni podejrzanych winnymi lub niewinnymi. Takie testy dostarczają najwięcej informacji, ale w praktyce są rzadkie i trudne do przeprowadzenia. (4) Test piórka na wietrze: hipotezy mają niską wyjątkowość i niską pewność, zaś przejście przez nie testu niczego zdecydowanie nie rozstrzyga. Zarówno przejście, jak i oblanie testu sa jak ,piórka na wietrze”. Wiele wyjaśnień wydarzeń historycznych ma właśnie taki charakter: prawdopodobnych prognoz. Na przykład, jeśli Hitler wydał rozkaz „ostatecznego rozwiązania kwestii żydowskiej”, powinniśmy prawdopodobnie odnaleźć pisemne dowody takiego rozkazu (Van Evera, 1997, s. 31-32).

Testując hipoteze, badacz posługujący się metodą SP odpowiada na pytanie „czy X było przyczyną Y w przypadku A?”, opierając się na danych pochodzących z badanego przypadku. Niekiedy pojedyncza obserwacja z badanego przypadku może dostarczyć poparcia lub podważyć przyczynową hipotezę, nawet jeśli setki innych obserwacji okazało się nieistotnych. Poszukiwanie decydujących wskazówek czyni SP podobnym do postępowania detektywa lub lekarza diagnozującego chorobę.

$\mathrm{Z}$ uwagi na formę tekstu ograniczę się do bardziej szczegółowego przedstawienia tylko jednej formy testu ilustrującej postępowanie w ramach SP. Test obręczy wymaga obecności dowodu ze studium przypadku, aby można było uznać hipotezę za prawdziwą. Jak już powiedziałem, nieprzejście przez hipotezę testu przemawia mocno przeciwko niej, ale przejście testu obręczy jej nie potwierdza. Zatem, hipoteza musi „przeskoczyć przez obręcz", aby uniknęła poważnych wątpliwości co do jej prawomocności. Jak w praktyce przeprowadzić test obręczy i jakie działania należy przeprowadzić? Zazwyczaj rozpoczynamy postępowanie od hipotezy: czy jeżeli $\mathrm{X}$ to $\mathrm{Y}$, a następnie zadajemy podstawowe pytania. Pytania te najczęściej przyjmują formę: czy zarówno X, jak i Y rzeczywiście się pojawiły? Czy X pojawiło się przed Y? Czy jest fizycznie lub teoretycznie możliwe, aby X wpłynęło na Y (Mahoney, 2015, s. 208)? Jeśli odpowiedzi na te pytania są negatywne, hipoteza nie przechodzi testu obręczy i musi zostać odrzucona. Jeśli hipoteza przechodzi test obręczy, badacz może rozpocząc poszukiwanie mechanizmów, które wiążą X i Y. Rodzaj danych wymaganych do przeprowadzenia testu obręczy będzie się różnił w zależności od tego czy hipoteza ustanawia konieczny warunek lub 
INUS warunek (akronim angielskiego wyrażenia: insufficient but non-redundant part of an unnecessary but sufficient condition - niewystarczająca i niezbywalna część niekoniecznego, ale wystarczającego warunku). Możemy założyć, że hipoteza zakładała, iż X było konieczne dla Y. Na przykład, zabicie arcyksięcia Franciszka Ferdynanda było konieczne dla wybuchu I wojny światowej. Test obręczy tej hipotezy można przeprowadzać na wiele sposobów. (1) Badacz może badać indukcyjnie pośrednie kroki między X i Y, próbując ustanowić łańcuch wydarzeń wiążący zakładaną przyczynę X z rezultatem Y. Jeżeli nie można wskazać takiego łańcucha poprzez indukcyjne SP, uzasadnione jest odrzucenie hipotezy. I przeciwnie, jeżeli można skonstruować narrację łączącą wydarzenia (zabójstwo arcyksięcia Franciszka Ferdynanda z wybuchem I wojny światowej), hipoteza przetrwała test obręczy. (2) Badacz testując hipotezę może starać się podać dane, które dowodzą prawdziwości hipotezy. Na przykład, badacz może być przekonany, że zabójstwo było konieczne dla wypowiedzenia przez Austrię wojny Serbii, co było warunkiem koniecznym dla wybuchu wojny kontynentalnej, która z kolei była konieczna dla wybuchu I wojny światowej. W tym przypadku test obręczy może przyjąć następującą formę. Jeśli zabójstwo było konieczne do wybuchu I wojny światowej, musiało wpłynąć na austriacki proces decyzyjny. Jeśli taki wpływ nie wystąpił, zabójstwo nie było istotne dla wybuchu wojny. Zadaniem badacza jest zatem przedstawienie dowodów wskazujących, że zabójstwo kształtowało strategiczne kalkulacje austriackich decydentów. Jeśli takie dowody zostaną odkryte, hipoteza przechodzi test. Badacz może następnie zapytać jak bardzo prawdopodobne jest odkrycie takich dowodów, jeśli zabójstwo nie było konieczne dla wypowiedzenia wojny przez Austrię (Mahoney, 1997, s. 208-209).

\section{Dyrektywy do śledzenia procesu}

W opisowych wymaganiach, jakie powinien spełniać badacz posługujący się metodą SP, zazwyczaj wskazuje się na konieczność posiadania „wiedzy o ogólnych stosunkach” i wiedzy „w formie specyficznych danych dotyczących badanego przypadku”. Aby badaniu przy wykorzystaniu SP zapewnić wysoką jakość, badacz powinien posiadać: (1) wiedzę o historii badanego przypadku; (2) wiedzę o możliwych do zastosowania teoriach i generalizacjach; (3) zdolność do przeprowadzenia logicznego rozumowania polegającego na połączeniu faktów o przypadku z wiedzą ogólną (Mahoney, 2015, s. 202).

Zwolennicy SP motywowani chęcią nadania metodzie spójności, a także obawami o zarzut jej narracyjności formułowanymi przez zwolenników badań ilościowych, opracowują bardziej precyzyjne wytyczne lub dyrektywy do prowadzenia badań przy jej użyciu. W ostatnich latach wzrasta zainteresowanie metodą SP. W rosnącej liczbie książek i artykułów poświęconych metodzie rozważa się nie tylko problemy jej ontologicznych i epistemologicznych fundamentów, ale także opracowuje kryteria jej standaryzacji i formalizacji. Próby takie podjęli D. Beach i R. B. Pedersen (2013, s. 162-170), A. Bennett i J. T. Checkel (2015, s. 17-22, 260-272), D. Waldner (2015, s. 126-132) oraz Ch. Trampusch i B. Palier (2016, s. 13-14).

Derek Beach i Rasmus B. Pedersen zaproponowali rodzaj listy kontrolnej dla trzech wariantów analizy SP w zależności od ich celu badawczego, którym może być: testowanie teorii; budowanie teorii oraz wyjaśnianie rezultatu procesu. Konstruowanie sche- 
matu badawczego powinniśmy rozpoczynać od określenia charakteru problemu i oceny czy w postępowaniu zasadne jest wykorzystanie metody SP oraz podjęcia decyzji, który wariant analizy może być zastosowany. Autorzy przedstawiają następnie cztery fazy procesu badawczego - wybór przypadku, konceptualizację, przeprowadzenie empirycznych testów i ocenę danych - dla każdego z trzech wariantów. Ze względu na charakter tekstu jestem zmuszony zrezygnować ze szczegółowego omówienia propozycji Beacha i Pedersena. Zamiast tego dokonuję analizy bardziej praktycznych propozycji pozostałych wymienionych autorów i przedstawiam je w formie ogólnych dyrektyw i rad dla posługujących się metodą SP.

Andrew Bennett i Jeffrey T. Checkel proponują trzyczęściowy standard dla prawidłowego stosowania metody SP. Metateoretycznie metoda powinna posiadać filozoficzną podstawę ontologicznie zgodną z mechanizmowym rozumieniem świata społecznego i akceptować metodologiczny pluralizm (na przykład, naukowy i krytyczny realizm, analityczny eklektyzm, pragmatyzm, interpretywizm). Kontekstualnie, powinna wykorzystywać ten pluralizm, zarówno do rekonstrukcji zakładanych procesów przyczynowych, jak i uwzględniać szersze strukturalno-dyskursywne konteksty. Metodologicznie, powinna traktować ekwifinalność poważnie (właściwość każdego systemu otwartego polegającą na tym, że w odróżnieniu od systemów nieożywionych, stan końcowy systemu otwartego może zostać osiagnięty różnymi drogami przy tych samych warunkach początkowych) i rozważać alternatywne ścieżki przyczynowe prowadzące do określonego skutku.

Kierując się tymi drogowskazami Bennett i Checkel formułuja „najlepsze praktyki SP" w formie 10 dyrektyw. (1) Bądź maksymalnie otwarty na alternatywne wyjaśnienia. Rozważaj alternatywne do twoich wyjaśnienia, pomimo kosztów, jakie to za sobą pociąga. Oceniając potencjalne wyjaśnienia, sprawdź czy nie zostały w nich pominięte istotne kategorie społecznego wyjaśniania oraz czy doceniłeś znaczenie strukturalnych lub normatywnych ograniczeń wpływających na działania agentów. (2) Bądź bezstronny w ocenie alternatywnych wyjaśnień. Pewne wyjaśnienia mogą zostać łatwo podważone w oparciu o zgromadzone dane, inne wymagają głębszej analizy. (3) Miej na uwadze potencjalną błędność danych, którymi dysponujesz. Pamiętaj, że dane dostarczają agenci, których instrumentalne motywy skłaniają do przekonania obserwatorów, że pewne wyjaśnienia są lepsze niż inne. (4) Rozważ w jakim stopniu (mniej lub bardziej prawdopodobnie) przypadek, który badasz poddaje się alternatywnym wyjaśnieniom. (5) Podejmij uzasadnioną decyzję od kiedy rozpocząć analizę. (6) Bądź zdeterminowany w gromadzeniu danych, ale podejmij uzasadnioną decyzję kiedy proces gromadzenia danych zakończyć. (7) Połącz SP w danym przypadku z porównywaniem do innych przypadków, jeśli uznasz, że jest to użyteczne dla realizacji celu badawczego i wykonalne. (8) Bądź otwarty na korzyści płynące z indukcji. (9) Wykorzystuj dedukcję, zadając pytanie: jeśli moje wyjaśnienie jest prawdziwe, jaki proces doprowadził do określonego rezultatu? (10) Pamiętaj, że rozstrzygający efekt SP jest wartościowy oraz że nie wszystkie wartościowe SP są rozstrzygające.

David Waldner koncentruje się na określeniu warunków „przyczynowej i eksplanacyjnej adekwatności SP". Rady Waldnera dla badacza korzystającego z metody SP wynikają z przekonania, że istotą metody jest wykorzystywanie danych do potwierdzania określonych wyjaśnień i podważania innych. Jako logikę testowania hipotez Waldner 
postuluje przyjęcie omówionych już propozycji testów zaproponowanych przez Stephena Van Evera (1997, s. 31-33), w których hipotezy mają różny stopień pewności i wyjątkowości. Tym samym testy mogą zostać użyte dla potwierdzania lub odrzucania proponowanych wyjaśnień. Zatem, według rad Waldnera, adekwatne SP musi: (1) opierać się na swego rodzaju przyczynowym grafie, którego poszczególne węzły są powiązane w taki sposób, że są razem wystarczające dla danego rezultatu; (2) SP musi opierać się na swego rodzaju mapie historii wydarzeń, w której ustanawia się prawomocną korespondencję między wydarzeniami w każdym studium przypadku i węzłami w przyczynowym grafie; (3) teoretyczne twierdzenia o przyczynowych mechanizmach wiążą następujące po sobie węzły w przyczynowym grafie, zaś empiria studiów przypadków pozwala na wnioskowanie, że wydarzenia były rzeczywiście generowane przez wskazane mechanizmy; (4) konkurencyjne hipotezy można zasadnie eliminować poprzez ich bezpośrednie testowanie lub wykazanie, że nie mogą spełnić trzech wskazanych wyżej kryteriów. Postępowanie badawcze prowadzone przy wykorzystaniu metody SP spełnia „standard kompletności”, jeśli zawiera zupełny przyczynowy graf; zupełny zestaw deskryptywnych wnioskowań prowadzących od konkretnego historycznego środowiska do grafu i zupełny zestaw wnioskowań o przyczynowych mechanizmach, które generują realizację łańcucha przyczynowego przedstawionego w grafie.

Christine Trampusch i Bruno Palier proponuja , dobre praktyki SP w dziesięciu krokach”. (1) Badacz posługujący się metodą SP musi być świadomy „swojej” ontologii. Przez ontologię proponuję rozumieć tutaj fundacyjne założenia, jakie każdy badacz powinien przyjąc odnośnie, na przykład, istoty społecznego świata, istoty przyczynowych stosunków w tym świecie, natury podmiotu sprawczego i stosunku między tym podmiotem a strukturami społecznymi. Na przykład, w ujęciu omawianych autorów czyni różnicę rozumienie mechanizmów przyczynowych jako działających determistycznie lub przygodnie i probabilistycznie. (2) W zależności od „stanu spraw”, dostępnych teorii, dostępności danych, stawianych pytań badawczych, badacz musi określić czy jego epistemologiczny interes wiąże się z indukcją czy dedukcją. Mówiąc krótko, czy jego celem jest budowa teorii czy testowanie teorii. Jednakże niezależnie od tego rozstrzygnięcia badacz powinien pamiętać, że SP w praktyce jest zawsze procesem iteratywnym, wędrowaniem przez kontinuum, którego bieguny tworzą teoria i dane empiryczne dotyczące danego przypadku(ów). (3) Badacz musi być transparentny w związku ze swoimi założeniami epistemologicznymi, gdy łączy SP z innymi metodami. (4) Niezależnie od wyboru przez badacza wariantu SP (indukcyjny lub dedukcyjny), potrzebuje on dobrej teorii, aby wiedzieć na czym skoncentrować swoją analityczną uwagę, które podmioty sprawcze (agentów) badać i jaką historyczną sekwencję wydarzeń analizować. Jakość badania przy korzystaniu z metody SP wzrasta, jeśli teorie z których korzysta potwierdziły swoją wartość we wcześniej przeprowadzonych badaniach. (5) Teoretyczna dźwignia badania prowadzonego przy wykorzystaniu metody SP w istotnym stopniu zależy od kierowanego teorią wyboru przypadków. Jako strategię wyboru przypadków można przyjąć: kluczowe przypadki, ekstremalne przypadki, najbardziej prawdopodobne i najmniej prawdopodobne przypadki, typowe przypadki lub anomalie. (6) Obserwacja procesu przyczynowego wymaga czasu, danych dotyczących kontekstu i wiedzy o indywidualnych przypadkach. Badacz może posługiwać się danymi z rozmaitych źródeł, wykorzystywać zarówno pierwszorzędne, jak i drugorzędne źródła i przeprowadzać wywiady. (7) Dodatkowym ubezpieczeniem dla dobrego SP 
może być wykorzystanie analizy kontrfaktualnej i eksperymentu myślowego. Oznacza to, że składniki sekwencyjnej serii wydarzeń lub elementy łańcucha przyczynowego mogą zostać ustanowione jako mentalne lub kognitywne konstrukcje w przypadkach, w których występują empiryczne luki. Należy jednak pamiętać, że takie postępowanie, choć ambitne, jest trudne i ryzykowne. (8) Badacz powinien starannie rozważyć kiedy analizowany proces(y) się rozpoczą i kiedy się zakończył. W literaturze poświęconej metodzie SP użytecznej wskazówki dostarcza w tym względzie propozycja rozróżniania między ekstensywnymi i intensywnymi procesami (Falleti, 2016, s. 4-6). (9) Prawidłowe postępowanie badawcze wykorzystujące metodę SP powinno uwzględniać także propozycje formułowane przez zwolenników „rewolucji transparentności” postulujące „transparentność danych”, „analityczną transparentność”, a także „wytwarzanie transparentności”. Postulat ten można spełnić dostarczając, na przykład on-line, apendiksu z danymi ilościowymi, co stało się już norma, ale także z danymi jakościowymi (na przykład, przeprowadzonymi wywiadami lub dokumentami). (10) Badacz powinien być świadomy, że w odróżnieniu od metody przyczynowej interpretacji pojedynczego przypadku, SP nie jest przyczynowym wyjaśnianiem osiagganym poprzez statystykę. Tym niemniej, w im większym stopniu badacz uwzględni wymienione kroki w swoim postępowaniu, tym lepsza może być jego przyczynowa interpretacja.

\section{Metoda śledzenia procesu w badaniu stosunków międzynarodowych}

W NSM badacze dość powszechnie akceptują pogląd o dwóch typach wnioskowania: deskryptywnym i przyczynowym. Celem wnioskowania deskryptywnego jest wykrywanie ogólnych tendencji w przedmiocie badania, zaś za cel wnioskowania przyczynowego uznaje się wyjaśnianie takich tendencji. Pomimo stanowiska zwolenników neopozytywistycznej filozofii nauki, że każdy „szanujący się badacz” powinien uznać wnioskowania przyczynowe za podstawowy cel nauki (King, Keohane, Verba, 1994), wielu przedstawicieli NSM nie podziela tej opinii, uznając, że w niedostatecznie rozwiniętej naukowo dyscyplinie wnioskowanie deskryptywne jest kluczowe (Friedrichs, 2016, s. 76). W mocniejszej formie stanowisko to wyraża teza o możliwości systematycznego badania powtarzalnych procesów środkami przyczynowo-deskryptywnego wnioskowania bez konieczności otwierania „czarnej skrzynki”, a więc bez poszukiwania mechanizmów, i jest ono określane jako wzorce procesu (process patterns). W tym przypadku, celem jest poszukiwanie powtarzalnej sekwencji interakcji, które można zaobserwować. Nie oznacza to odrzucania metody SP, a jedynie zwrócenie uwagi, że wymaga ona zawsze formułowania empirycznych generalizacji (na przykład, o demokratycznym pokoju, o anarchiczności systemu międzynarodowego).

W NSM istotnego impulsu dla wyjaśniania opartego o koncepcję mechanizmów przyczynowych dostarczyło wprowadzenie do agendy dyscypliny filozofii naukowego i krytycznego realizmu oraz problematyki przyczynowości (szerzej: Gałganek, 2016). Wprowadzenia tego dokonali, w szczególności, David Dessler (1991), Alexander Wendt i Ian Shapiro (1992), Colin Wight i Heikki Patomäki (2000), Heikki Patomäki (2002), Colin Wight (2006), Jonathan Joseph i Colin Wight (2010), Miljia Kurki (2008) oraz, w odniesieniu do problemu przyczynowości, Richard Ned Lebow (2014). 
Aczkolwiek SP jest często używane do wyjaśniania w badaniach pojedynczych przypadków, znajduje również zastosowanie, poprzez odwoływanie się do ogólnych teorii, w badaniu wielu przypadków. Przykładami zastosowania metody SP w badaniu stosunków międzynarodowych są: badania dotyczące bezpieczeństwa broni nuklearnej (Sagan, 1993), analiza amerykańskiego „nuklearnego taboo” po II wojnie światowej (Tannenwald, 1999), badania nad wypowiadaniem wojny (Goemans, 2000), badania inspirowane hipotezą o demokratycznym pokoju (Schultz, 2001), badania nad rolą przywództwa w militarnych interwencjach (Saunders, 2011), analizy: incydentu w Faszodzie między Francją i Wielką Brytanią z 1898 roku, rozszerzenia celów i środków w niemieckiej strategii wojennej w latach 1916-1917 oraz braku sowieckiej interwencji militarnej w Europie Wschodniej w 1989 roku (Bennett, 2010), zakończenia zimnej wojny (Evangelista, 2015), interwencji w Iraku w 2003 roku (Bennett, 2015).

W NSM podkreśla się, że SP może być także efektywną metodą oceny rywalizujących teorii stosunków międzynarodowych w odniesieniu do ich teoretyzacji wielu kluczowych problemów stosunków międzynarodowych. Nina Tannenwald wskazuje przykłady prac w NSM, których autorzy posługują się SP, obejmujące takie kwestie jak: dynamika kryzysów międzynarodowych, odstraszanie, przyczyny wojny, wyścig zbrojeń i kontrola zbrojeń, koniec zimnej wojny, demokratyczny pokój, wpływ idei na strategię i konflikt, postkonfliktowe tranzycje, humanitarne i antyhumanitarne normy i praktyki. Wskazuje ona również, że metodę można wykorzystać do badania procesów konstytutywnych, a nie tylko przyczynowych (Tannenwald, 2015, s. 222). Jednak w tej ostatniej kwestii, inni badacze w NSM zajmują mniej optymistyczne stanowisko. Vincent Pouliot stosunek między interpretywistami i zwolennikami metody SP określa jako wzajemną obojętność, podejrzliwość i lekceważenie. W konsekwencji wśród badań stosunków międzynarodowych prowadzonych w perspektywie interpretywistycznej czy poststrukturalnej trudno wskazać prace posługujące się metodą SP.

\section{Metoda śledzenia procesu w wyjaśnianiu zakończenia zimnej wojny}

Moim celem w tym punkcie nie jest udzielenie odpowiedzi na pytanie kiedy zakończyła się zimna wojna (dalej ZW), ani też, która z konkurujących teorii dostarcza najlepszego wyjaśnienia jej końca. Staram się raczej: (1) zasugerować, że w oparciu o ,pojedyncze” wydarzenie metoda SP może pomóc ocenić mocne i słabe strony konkurujących teorii i rozpoznawanych przez nie mechanizmów oraz (2) zilustrować, tam gdzie to uzasadnione, wykorzystanie dyrektyw składających się na „najlepsze praktyki” prowadzenia SP.

Przywołuję powtórnie stanowisko Andrew Bennetta i Colina Elmana, którzy podkreślają że śledząc proces badacz może posługiwać się zarówno indukcją jak i dedukcją. Postępowanie indukcyjne może odsłonić potencjalnie przyczynowy proces, którego badacz nie teoretyzował a priori, zaś postępowanie dedukcyjne, o ile badacz dysponuje teorią, może sugerować, jakie wydarzenie powinno pojawić się w badanym przypadku, jeśli teoria dostarcza dobrego wyjaśnienia. W zależności od teorii można zakładać wręcz zajście określonych wydarzeń i traktować je jako warunki konieczne. Zatem, w dedukcyjnym typie SP badacz rozpoczyna badanie od teorii i ocenia prawomocność empirycz- 
nych przewidywań wyprowadzanych z teorii poprzez porównanie danych dotyczących badanego przypadku z przewidywaniami teorii w formie hipotez o mechanizmach przyczynowych.

Jednakże, ponieważ wyjaśnienia zakończenia ZW formułowane przez badaczy stosunków międzynarodowych - zmiana w równowadze siły, relatywny upadek Związku Sowieckiego, wpływ ekonomicznej globalizacji czy ideowa atrakcyjność demokracji i kapitalizmu - nie nadają się zbyt dobrze do objaśniania wydarzeń, metoda SP dostarcza sposobu oceny eksplancji o końcu ZW poprzez powiązanie ogólnych teorii stosunków międzynarodowych ze specyficznymi wydarzeniami ZW (od militarnej interwencji poprzez kontrolę zbrojeń do podstawowych idei określających kierunki polityki zagranicznej) (Evangelista, 2015, s. 153). Na przykład, celem Matthew Evangelisty jest koncentracja na zjawisku końca ZW poprzez oparcie się na rozmaitych wyjaśnieniach formułowanych przez badaczy, a tym samym na powiązaniu głównych teoretycznych podejść ze specyficznymi politycznymi, społecznymi i psychologicznymi mechanizmami, które musiały działać, aby mogły służyć jako eksplanacje kluczowych wydarzeń, które stanowiły koniec ZW. Uzasadnienie dla wyboru do tego celu problemu zakończenia ZW jest podwójne: (1) wykorzystano wiele rywalizujących teorii w poszukiwaniu odpowiedzi na pytanie o przyczyny zakończenia ZW; (2) według wielu badaczy stosunków międzynarodowych koniec ZW podważył prawomocność wiodących teorii w NSM, prowadząc do debaty między krytykami i obrońcami tych teorii oraz otworzył przestrzeń do ewentualnych teoretycznych innowacji i postępu. Evangelista przywołuje cztery grupy teorii: podejścia realistyczne; podejścia ideacyjne; podejścia koncentrujące się na wewnętrznych politycznych koalicjach; podejścia psychologiczne i osobowościowe. W szczególności jednak, celem Evangelisty nie jest ukazanie metody SP poprzez ocenę wszystkich konkurujących teorii, ale poprzez skoncentrowanie się na jednym wydarzeniu i rozważenie teorii najbardziej związanych z nim. Evangelista dąży w szczególności do wskazania punktów w śledzeniu procesu, które doprowadziły do przemówienia M. Gorbaczowa w ONZ w grudniu 1988 roku (proklamacja ,wolności wyboru” dla satelitów z Europy Wschodniej i zapowiedź jednostronnej defensywnej restrukturyzacji i redukcji Armii Czerwonej o 500 tys. żołnierzy) i ukazania, jak można oceniać mechanizmy, które wskazują poszczególne teorie z punktu widzenia tego pojedynczego wydarzenia.

Wybór przez Evangelistę przemówienia Gorbaczowa z 1988 roku jako kluczowego wydarzenia kończącego ZW był inspirowany serią artykułów amerykańskiego dziennikarza i zwolennika realizmu politycznego Waltera Lippmanna (1889-1974), który odpowiadając na słynną analizę celów Związku Sowieckiego George’a Kennana z 1947 roku, twierdził, że dopóki nie zostanie zawarte porozumienie, którego rezultatem będzie wycofanie się Armii Czerwonej z centrum Europy, Związek Sowiecki będzie kontrolował Europę Wschodnią i zagrażał Europie Zachodniej. Harrison Wagner, przywołując rozpoznanie Lippmanna dotyczące przyczyn ZW, proponuje swoją tezę dotycząca jej zakończenia. Według Wagnera ZW zakończyła się, gdy załamała się kontrola Związku Sowieckiego nad Europą Wschodnią i sowieckie militarne zagrożenie Zachodu przestało stanowić palący problem (Wagner, 1993, s. 80).

(1) „Wolność wyboru” i defensywna restrukturyzacja. Evangelista wskazuje, że proklamacja ,wolności wyboru” i jednostronna defensywna restrukturyzacja Armii Czerwonej ogłoszona przez Gorbaczowa miała swojego poprzednika w reformie prze- 
prowadzonej przez N. Chruszczowa w drugiej połowie lat 50. XX wieku. Sowieccy zwolennicy redukcji zapowiedzianej w 1988 roku przywoływali przykład Chruszczowa jako inspirację dla inicjatywy Gorbaczowa. Inicjatywa Chruszczowa miała swoje przyczyny częściowo w spadku wzrostu liczby robotników i produktywności pracy, którym można było zaradzić poprzez zwiększenie dopływu siły roboczej w formie zdemobilizowanych żołnierzy. Poprzez analogię można by zatem zakładać, że podobne cele leżały u źródeł decyzji Gorbaczowa. Metoda SP wymaga jednak dostarczenia dowodów, w jakim zakresie decyzja Gorbaczowa była związana z potrzebami gospodarki, a w jakim ze specyficznymi celami polityki zagranicznej. Podczas gdy Chruszczow łączył redukcję sił konwencjonalnych z rozwojem sowieckiego arsenału nuklearnego i rakietowego, Gorbaczow, przeciwnie, dążył do redukcji poziomu zagrożenia nuklearnego i postrzegał redukcję sił konwencjonalnych jako komplementarną i sprzyjającą realizacji tego celu. Z punktu widzenia metody SP, analiza wydarzeń prowadzących do 1988 roku może korzystać z analizy wcześniejszych wydarzeń poprzez porównanie przypadków. Postępowanie takie realizuje pkt 7 ,najlepszych praktyk" SP Bennetta i Checkela (połącz SP w danym przypadku z porównywaniem do innych przypadków, jeśli uznasz, że jest to użyteczne dla realizacji celu badawczego i wykonalne).

(2) Ekonomiczny upadek i test obręczy. Biorąc pod uwagę, że zarówno podejścia realistyczne, jak i ideacyjne oraz koncentrujące się na politycznych koalicjach wskazują na rolę czynników ekonomicznych, można uznać, że teza o ekonomicznym upadku Związku Sowieckiego jako przyczynie końca ZW z łatwością przechodzi test obręczy. Gdyby badacz w swoim postępowaniu nie znalazł dowodów potwierdzających, że liderzy Związku Sowieckiego byli w szczególny sposób zainteresowani problemami ekonomicznymi, byłby zmuszony wykluczyć ten czynnik ze swojego wyjaśniania końca ZW. Jednakże takich dowodów jest bardzo dużo. Evangelista interpretuje jednak ten problem odwrotnie. Wskazuje, że niezadowolenie ze stanu sowieckiej ekonomii i systemu centralnego planowania było wśród rządzących zjawiskiem endemicznym. Zbyt łatwe przejście testu obręczy powinno skłaniać zatem do „dezagregacji” wyjaśniania ekonomicznego i identyfikacji jego bardziej szczegółowych wariantów w stosunku do istniejących danych. Na przykład, ,ciężaru imperium", endogeniczności sowieckiego kryzysu, nieskuteczności centralnego planowania, wydatków zbrojeniowych czy kosztów związanych z subsydiowaniem satelitów.

(3) „Złapanie oddechu” i test dymiącego pistoletu. Jeden z wariantów tezy o ekonomicznym upadku Związku Sowieckiego, jako bezpośredniej motywacji dla przemówienia Gorbaczowa z 1988 roku głosi, że jego polityczni i wojskowi liderzy podzielali przekonanie o konieczności poprawy militarnej pozycji poprzez krótkoterminowe ograniczenie wydatków wojskowych (,złapanie oddechu”) w celu osiagnięcia długoterminowej technologicznej przewagi konkurencyjnej. Tezy formułowane w tym kontekście głoszą że celem przemówienia Gorbaczowa w 1988 roku była poprawa klimatu międzynarodowego umożliwiająca dostęp do zachodniej technologii niezbędnej dla sowieckiej militarnej modernizacji oraz zmiana niekorzystnej dla Związku Sowieckiego nierównowagi militarno-technologicznej. W postępowaniu badawczym przy wykorzystaniu metody SP można posłużyć się testem dymiącego pistoletu w celu dostarczenia poparcia tezie o krótkoterminowym ograniczeniu wydatków zbrojeniowych, aby tym skuteczniej konkurować $\mathrm{w}$ długoterminowym jakościowym postępie z zachodnimi siłami zbrojnymi. Żaden badacz nie znalazł jednak dowodów na „dymiący pistolet” w formie obrony 
przez sowieckich wojskowych tez o redukcji wydatków zbrojeniowych, rynkowych reformach, otwarciu w handlu międzynarodowym oraz nowych inwestycjach w celu przebudowy sowieckiego kompleksu militarnego.

(4) Obserwowalne implikacje dedukcyjnych hipotez. Stephen Brooks i William Wohlforth uważają, że nie istnieje teoretyczne uzasadnienie, aby przewidywać wewnętrzny konsensus w kwestii reorientacji sowieckiej polityki zagranicznej (2003, s. 297). Odmienne stanowisko w tej kwestii można wyprowadzić z dedukcyjnego założenia teorii realizmu politycznego, które głosi, że państwo może być modelowane w analitycznych celach, jako unitarny i racjonalny aktor. Szczególnie, w kwestiach bezpieczeństwa narodowego, można zakładać, że wszystkie grupy społeczne danego państwa będą wspierać zachowanie jego terytorialnej i politycznej integralności. Na tej podstawie za zasadne można uznać przewidywanie, że sowiecki kompleks wojskowy będzie elementem reformistycznej koalicji. Słuszne jest zatem oczekiwać, że istnieją dowody przemawiające za taką interpretacją w formie, na przykład, wojskowych analiz czy też planów firmowanych przez ministerstwo obrony, poprzedzających przemówienie Gorbaczowa z 1988 roku (test dymiącego pistoletu). Jednak takich planów nie było i test dymiącego pistoletu nie potwierdza udziału sowieckich wojskowych w inicjowaniu tego rodzaju reform. Przeciwnie, istnieją liczne dowody świadczące o tym, że inicjatywa reform wyszła od cywilnej administracji Gorbaczowa, a zadaniem wojskowych była jedynie jej implementacja.

(5) Idź w przeszłość. Rozszerzanie okresu obejmowanego badaniem i otwarcie na korzyści płynące z indukcji (pkt 8 ,najlepszych praktyk” SP) pozwala na zgromadzenie większej liczby danych, które mogą być pomocne w ocenie konkurencyjnych wyjaśnień zakończenia ZW. Na przykład, Robert English nadając w swoim SP większego znaczenia czynnikom ideacyjnym i krytykując realistów za ich ekonomiczny determinizm, wskazuje na znaczenie antyizolacjonistycznych, globalistycznych i socjaldemokratycznych idei, które dostarczyły reformistycznych politycznych inspiracji w końcu lat 50 . i w latach 60. XX wieku (English, 2003, s. 245). Śledzenie militarnego komponentu w przemówieniu Gorbaczowa z 1988 roku odsyła do inspiracji płynących z transnarodowych ruchów kontroli zbrojeń, europejskich badań nad pokojem, Komisji Olofa Palmego, które wprowadziły zagadnienie obronnej restrukturyzacji do debaty w Związku Sowieckim (cywilni analitycy, część emerytowanych wojskowych). Liczne źródła potwierdzają, że dla Gorbaczowa atrakcyjność idei defensywnej restrukturyzacji wyrażała się otwarciem drogi do zmniejszenia nuklearnego zagrożenia dla obu stron (,,wspólne bezpieczeństwo") i wzmocnieniem perspektywy nuklearnego rozbrojenia (Evangelista, 2015, s. 173). Dla metody SP dodatkowego „politycznego okna” dostarcza katastrofa elektrowni atomowej w Czarnobylu w kwietniu 1986 roku, łącząc wyjaśnienia odwołujące się do znaczenia idei i politycznych koalicji. Gorbaczow i jego zwolennicy wykorzystali skutki katastrofy do przedłużenia jednostronnego sowieckiego moratorium na próby nuklearne. Również dla wielu wysokich sowieckich wojskowych (na przykład, marszałka Siergieja Achromiejewa (1923-1991)), Czarnobyl stanowił punkt zwrotny $\mathrm{w}$ postrzeganiu zagrożeń związanych z bronią nuklearną. Zatem, rozszerzenie okresu obejmowanego śledzeniem procesu o wiele lat przed wystapieniem wyjaśnianego wydarzenia pozwala na odsłonięcie istotnych eksplanacyjnych czynników, które bez takiego rozszerzenia zostałyby pominięte. To samo można powiedzieć o analizie przyszłości i możliwości identyfikacji czynników, które wystąpiły po wyjaśnianym wydarzeniu. 
Z oczywistych względów tak skrótowa analiza stanowi jedynie zapowiedź korzyści, jakie metoda SP może przynieść badaczowi. Chociaż, także ona nie gwarantuje zwycięstwa w ,teoretycznych wojnach”. Jak stwierdza William C. Wohlforth, broniący realistycznej przed konstruktywistyczną eksplanacją zakończenia ZW, nawet jeśli systemowe presje wspierały szerokie zmiany w zgodzie z celami zakładanymi przez Gorbaczowa, trudno wykazać niezależny przyczynowy wpływ idei, jaki wielu badaczy ZW początkowo zakładało. Zatem, według Wohlfortha, wiele badań błędnie oceniło rolę idei w zakończeniu ZW, zaś mechanizmy przyczynowe, które łączono z ideami było $\mathrm{w}$ istocie endogeniczne ze zmieniającymi się bodźcami ekonomicznymi. Ostatecznie Wohlforth przyznaje jednak, że z konstruktywistycznymi mechanizmami, procesami i argumentami, można zaproponować znacznie pełniejsze wyjaśnienie końca ZW, aniżeli bez nich (Wohlforth, 2011, s. 449). W przypadku zakończenia ZW, jak we wszystkich innych przypadkach, relacja między ogólnymi teoriami i wyjątkowymi wydarzeniami jest łamigłówką.

\section{Wątpliwości związane z metodą śledzenia procesu}

Na zakończenie artykułu wskazuję kilka wątpliwości związanych z metodą SP:

(1) Niektórzy badacze odnoszą się z podejrzliwością do ogólnej tezy o roli mechanizmów w naukach społecznych z dwóch powodów. Po pierwsze, z powodu wątpliwości dotyczących wszystkich ogólnych metodologicznych dyspozycji w nauce. W praktyce bowiem, wszystkie metodologiczne reguły wymagają dziedziny i kontekstu szczegółowej wiedzy, aby być użyteczne. Na przykład, ogólna dyspozycja dążenia do prostoty często nie sprawdza się, jeśli przedmiot badania jest skomplikowany. Podobnego typu watpliwości można formułować w odniesieniu do roli mechanizmów w naukach społecznych. Po drugie, wątpliwości wobec potrzeby mechanizmów wynikają z faktu, że tezie tej nadaje się wiele różnych interpretacji i motywacji, które są logicznie niespójne (Kincaid, 2012, s. 48). Prócz tego, pomimo szerokiego niezadowolenia z logiczno-pozytywistycznych modeli wyjaśniania, nie wszyscy filozofowie i nie wszyscy przedstawiciele nauk społecznych zgadzają się, że przyczynowe wyjaśnienia wymagają przyczynowych mechanizmów.

(2) Pozytywny aspekt wskazywania na znaczenie mechanizmów w przyczynowym wyjaśnianiu w naukach społecznych opiera się na prostej przesłance, że możemy wykazać, że X jest przyczyną Y, jeśli odkryjemy mechanizm prowadzący od X do Y. Problem leży w łatwości wyobrażania sobie społecznych mechanizmów, poprzez które prawie każda makropoziomowa społeczna zmienna może wpływać na inną zmienną. Rzadko spotkamy przypadek, w którym nie moglibyśmy wyobrazić sobie wiarygodnego mechanizmu wiążącego dwie zmienne reprezentujące pewne aspekty zjawiska społecznego. Nierozwiązany pozostaje jednak ciagle problem jak rozpoznać mechanizmy, aby nie narazić się na kłopot obecny w badaniach ilościowych, a związany z czynnikami zakłócającymi lub fałszywą korelacją które pojęcie mechanizmowej przyczynowości miało rozwiązać (Steel, 2008, s. 198). Proponowany zwykle sposób postępowania w tej kwestii (zob. szerzej: Little, 1991, s. 30) polega na identyfikacji przyczynowych mechanizmów w oparciu o wcześniej posiadaną wiedzę o probabilistycznych zależnościach między zmiennymi. Nie rozwiązuje to jednak kwestii czynników zakłócających, ponieważ probabilistyczna zależność może być wynikiem innej przyczyny, aniżeli wskazane przez nas X jako przyczyna Y. 
(3) Ta sama wątpliwość dotyczy rozumienia metody SP przez A. George'a i A. Bennetta (2005, s. 206-207). Autorzy posługują się analogią z kostkami domina w celu ilustracji swojego rozumienia SP. Wyobraźmy sobie ustawione w szereg kostki domina. Następnie opuśćmy pokój. Kiedy wrócimy widzimy, że pierwsza i ostatnia kostka zostały przewrócone, zaś kostki znajdujące się między nimi zostały zasłonięte. Aby dowiedzieć się czy przewrócenie pierwszej kostki było przyczyną przewrócenia się ostatniej musimy odsunąć zasłonę i sprawdzić czy pozostałe kostki także przewróciły się we właściwym kierunku. Odsuwanie zasłony jest działaniem analogicznym do SP w rozumieniu George'a i Bennetta. Zgodnie z tym rozumieniem SP jest testowaniem hipotez o ,rzeczywistych” przyczynach wydarzenia. Przykład domina pokazuje, że hipotezy o rzeczywistych przyczynach określonego skutku często mają swoje implikacje dla określania jakie wydarzenia wystapiły między (domniemaną) przyczyną i określonym skutkiem. W rozumieniu George'a i Bennetta SP jest metodą testowania hipotez o rzeczywistych przyczynach przez zbadanie czy przewidywana sekwencja pośrednich wydarzeń faktycznie wystapiła (Steel, 2008, s. 186). Pomimo sensowności analogii jej niedostatkiem jest ten sam problem, który obecny jest w wyjaśnieniu D. Little. Obecność sekwencji przewidywanych wydarzeń pomiędzy domniemaną przyczyną i skutkiem nie jest wystarczająca do ustanowienia rzeczywistej przyczynowości. Konieczne jest także wykazanie, że ta sekwencja nie jest koincydencja. Aby to wykazać, podobnie jak w argumentacji D. Little, musimy odwołać się do pewnej przyczynowej generalizacji. Trudno jednak wyobrazić sobie jak możemy poznać tę przyczynową generalizację bez wnioskowania z danych statystycznych (Steel, 2008, s. 186). Ostatecznie, Daniel Steel przekonuje, że metoda SP jest nierozerwalnie związana $\mathrm{z}$ wnioskowaniem przyczynowym na podstawie danych statystycznych. Obie metody nie wykluczają się wzajemnie i mogą przyczynić się do zdobywania wiedzy o przyczynowych stosunkach, zaś metoda SP nie ogranicza się do sytuacji, w której dysponujemy wiarygodnymi danymi statystycznymi. Jednakże, bez pomocy danych statystycznych badacz posługujący się metodą SP może mieć jedynie nadzieję na ustanowienie jakościowych przyczynowych sądów. Problem ten podnoszą także inni badacze. Blatter i Blume postrzegają metodę śledzenia procesu jako narracyjne poznawanie przypadków bez klarownej podstawy umożliwiającej generalizacje wychodzące poza badane przypadki (Blatter, Blume, 2008, s. 29-34).

\section{Bibliografia}

Beach D., Pedersen B. R. (2013), Process-Tracing Methods. Foundations and Guidelines, University of Michigan, Ann Arbor.

Bennett A. (2004), Case Study Methods: Design, Use, and Comparative Advantages, w: Models, Numbers, and Cases. Methods for Studying International Relations, red. D. F. Sprinz, Y. WolinskyNahmias, University of Michigan Press, Ann Arbor.

Bennett A., Elman C. (2007), Case Study Methods in the International Relations Subfield, „Comparative Political Studies", vol. 40, no. 2.

Bennett A. (2010), Process Tracing and Causal Inference, w: Rethinking Social Inquiry Diverse Tools, Shared Standards, red. H. E. Brady, D. Collier, Rowman and Littlefield Publishers, Lanham.

Bennett A. (2015), Using Process Tracing to Improve Policy Making: The (Negative) Case of the 2003 Intervention in Iraq, ,Security Studies”, no. 24. 
Bennett A., Checkel J. T. (red.) (2015), Process Tracing. From Metaphor to Analytic Tool, Cambridge University Press, Cambridge.

Bhaskar R. [2008 (1978)], A Realist Theory of Science, Routledge, London-New York.

Bhaskar R. [2009 (1979)], The Possibility of Naturalism. A Philosophical Critique of the Contemporary Human Sciences, Routledge, London-New York.

Bhaskar R. (2011), Reclaiming Reality. A Critical Introduction to Contemporary Philosophy, Routledge, London-New York.

Blatter J. K., Blume T. (2008), Co-variation and Causal Process Tracing Revisited: Clarifying New Directions for Causal Inference and Generalization in Case Study Methodology, „Qualitative Methods", vol. 6.

Brady E. H., Collier D. (2010), Rethinking Social Inquiry. Diverse Tools, Shared Standards, Rowman and Littlefield Publishers, Lanham.

Brooks S. G., Wohlforth W. C. (2003), Economic Constraints and the End of the Cold War, w: Cold War Endgame: Oral History, Analysis, Debates, red. W. C. Wohlforth, State University Press, University Park, Pennsylvania.

Bunge M. [2009 (1979)], Causality and Modern Science, Transaction Publishers, New BrunswickLondon.

Bunge M. (2006), Chasing Reality: Strife over Realism, University of Toronto Press, Toronto.

Bunge M. (2012), Evaluating Philosophies, Springer, Dordrecht.

Checkel J. T. (2008), Process Tracing, w: Qualitative Methods in International Relations. A Pluralist Guide, red. A. Klotz, D. Prakash, Palgrave Macmillan, Houndmills.

Czaputowicz J., Wojciuk A. (2014), IR scholarship in Poland: the state of the discipline 25 years after the transition to democracy, „Journal of International Relations and Development”, vol. 17, no. 1.

Dessler D. (1991), Beyond Correlations. Toward a Causal Theory of War, „International Studies Quarterly", vol. 35 , no. 3 .

Elster J. (1989), Nuts and Bolts for the Social Sciences, Cambridge University Press, Cambridge.

Elster J. (1998), A Plea for mechanisms, w: Social Mechanisms. An Analytical Approach to Social Theory, red. P. Hedström, R. Swedberg, Cambridge University Press, New York.

Elster J. (2007), Explaining Social Behavior. More Nuts and Bolts for the Social Sciences, Cambridge University Press, Cambridge.

English R. D. (2003), The Road(s) Not Taken: Causality and Contingency in Analysis of the Cold War's End, w: Cold War Endgame: Oral History, Analysis, Debates, red. W. C. Wohlforth, State University Press, University Park, Pennsylvania.

Evangelista M. (2015), Explaining the Cold War's end: process tracing all the way down?, w: Process Tracing. From Metaphor to Analytic Tool, red. A. Bennett, J. T. Checkel, Cambridge University Press, Cambridge.

Falleti T. G., Mahoney J. (2015), The Comparative Sequential Method, w: Advances in Comparative Historical Analysis: Resilience, Diversity, and Change, red. J. Mahoney, K. Thelen, Cambridge University Press, Cambridge.

Falleti T. G. (2016), Process Tracing of Extensive and Intensive Processes, „New Political Economy”, 3.02.2018, http://dx.doi.org/10.1080/13563467.2015.1135550.

Friedrichs J. (2016), Causal Mechanisms and Process Patterns in International Relations. Thinking Within and Without the Box, „St. Antony's International Review” 2016, vol. 12, no. 1.

Gałganek A. (2016), Przyczynowość w nauce o stosunkach międzynarodowych, „Przegląd Politologiczny", vol. 16, nr 4.

George A. L., McKeown T. J. (1985), Case Studies and Theories of Organizational Decision Making', „Advances in Information Processing in Organizations", vol. 2. 
George A. L., Bennett A. (2005), Case Studies and Theory Development in the Social Sciences, The MIT Press, Cambridge.

Goemans H. E. (2000), War and Punishment. The Causes of War Termination and the First World War, Princeton University Press, Princeton-New York.

Hedström P., Swedberg R. (1998), Social Mechanisms: An Introductory Essay, w: Social Mechanisms. An Analytical Approach to Social Theory, red. P. Hedström, R. Swedberg, Cambridge University Press, New York.

Hedström P. (2008), Studying Mechanisms to Strengthen Causal Inferences in Quantitative Research, w: The Oxford Handbook of Political Methodology, red. J. M. Box-Steffensmeier, H. E. Brady, D. Collier, Oxford University Press, Oxford.

Hempel C. (1942), The Function of General Laws in History, „The Journal of Philosophy”, vol. 39, no. 2 .

Joseph J., Wight C. (red.) (2010), Scientific Realism and International Relations, Palgrave Macmillan, Basingstoke.

Kincaid H. (2012), Mechanisms, Causal Modeling, and the Limitations of Traditional Multiple Regression, w: The Oxford Handbook of Philosophy of Social Science, red. H. Kincaid, Oxford University Press, New York.

King G., Keohane R. O., Verba S. (1994), Designing Social Inquiry: Scientific Inference in Qualitative Research, Princeton University Press, Princeton.

Kurki M. (2008), Causation in International Relations. Reclaiming Causal Analysis, Cambridge University Press, Cambridge.

Lipset S. M. (1959), Political Sociology, w: Sociology Today: Problems and Prospects, red. R. K. Merton, L. Broom, L. S. Cottrell, Basic Books, New York.

Little D. (1991), Varieties of Social Explanation: An Introduction to the Philosophy of Social Science, Westview Press, Boulder.

Little D. (1998), Microfoundations, Method, and Causation, Transaction Publishers, New BrunswickNew York.

Little D. (2010), New Contributions to the Philosophy of History, Springer, Dordrecht.

Ławniczak K. (2013), Process tracing. Śledzenie mechanizmów przyczynowych, w: Metody jakościowe i ilościowe w badaniu organizacji i działania Unii Europejskiej, red. K. Ławniczak, Wydawnictwo Wydziału Dziennikarstwa i Nauk Politycznych Uniwersytetu Warszawskiego, Warszawa.

Mahoney J. (2015), Process Tracing and Historical Explanation, „Security Studies”, no. 24.

Ned Lebow R. (2014), Constructing Cause in International Relations, Cambridge University Press, Cambridge.

Patomäki H., Wight C. (2000), After Postpositivism? The Promises of Critical Realism, „International Studies Quarterly", vol. 44, no. 2.

Patomäki H. (2002), After International Relations. Critical Realism and the (Re)construction of World Politics, Routledge, London-New York.

Rohlfing I. (2012), Case Studies and Causal Inference: An Integrative Framework Research, Palgrave Macmillan, Basingstoke.

Sagan S. D. (1993), The Limits of Safety, Princeton University Press, Princeton-New York.

Saunders E. N. (2011), Leaders at War: How Presidents Shape Military Interventions, Cornell University Press, Ithaca-New York.

Schultz K. A. (2001), Democracy and Coercive Diplomacy, Cambridge University Press, Cambridge.

Steel P. D. (2008), Across the Boundaries. Extrapolation in Biology and Social Science, Oxford University Press, Oxford-New York.

Tannenwald N. (1999), The Nuclear Taboo: The United States and the Normative Basis of Nuclear Non-Use, „International Organization”, vol. 53, no. 3. 
Tannenwald N. (2015), Process Tracing and Security Studies, „Security Studies”, no. 24.

Trampusch Ch., Palier B. (2016), Between X and Y: How Process Tracing Contributes to Opening the Black Box of Causality, „New Political Economy”, 18.01.2018, http://dx.doi.org/10.1080/135 63467.2015.1134465.

Van Evera S. (1997), Guide to Methods for Students of Political Science, Cornell University Press, Ithaca-London.

Wagner R. H. (1993), What was Bipolarity?, „International Organization”, vol. 47, no. 1.

Waldner D. (2012), Process Tracing and Causal Mechanisms, w: The Oxford Handbook of Philosophy of Social Science, red. H. Kincaid, Oxford University Press, New York.

Waldner D. (2015), What Makes Process-tracing Good? Causal Mechanisms, Causal Inference, and the Completeness Standard in Comparative Politics, w: Process Tracing in the Social Sciences: From Metaphor to Analytic Tool, red. A. Bennett, J. T. Checkel, Cambridge University Press, Cambridge.

Wendt A., Shapiro I. (1992), The Difference Realism Makes: Social Science and the Politics of Consent, „Politics \& Society”, vol. 20, no. 2.

Wight C. (2006), Agents, Structures and International Relations. Politics as Ontology, Cambridge University Press, Cambridge.

Wohlforth W. C. (2011), No One Loves a Realist Explanation, „International Politics”, vol. 48, no. $4-5$.

Ylikoski P. (2012), Micro, Macro, and Mechanisms, w: The Oxford Handbook of Philosophy of Social Science, red. H. Kincaid, Oxford University Press, New York.

\section{Process tracing and causal mechanisms in research on international relations}

\section{Summary}

The article presents a qualitative method known as process tracing and exemplifies its use in the study of international relations. Firstly, the general characteristics of process tracing are shown. Secondly, the debate in social sciences on the understanding of causal mechanisms and causal inference is discussed, and whether process tracing is useful in testing hypotheses. Thirdly, different types of directives that guide the research procedure within the framework of process tracing are presented. Fourthly, the final part of the article demonstrates the implementation of process tracing in International Relations on the example of the analysis of the end of the Cold War. The article is concluded with a few doubts the method raises.

The aim of the article is to introduce a qualitative research method to the Polish studies of International Relations. This method has not been used by Polish researchers, although most of them declare their methodological standpoint as a qualitative approach. The author justifies and illustrates the belief that the method of process tracing can be strongly recommended in solving problems related to the identification of causal relations in International Relations.

The author uses the content analysis method in the article. The method of process tracing is presented based on the analysis of the texts of renowned supporters of the method in the Philosophy of Science and International Relations and of works dedicated to the problems of international relations studied using this method.

The results of the analysis make it possible to formulate recommendations for the application of the method to study international relations. The author also presents the weaknesses of this method, which every scholar employing it should be aware of.

Key words: process tracing, causal mechanisms, testing hypotheses, directives, the end of the Cold War 